\title{
OPEN Author Correction: Pivotal role of CD103 in the development of psoriasiform dermatitis
}

\begin{abstract}
Takehito Fukui, Tomohiro Fukaya, Tomofumi Uto, Hideaki Takagi, Junta Nasu, Noriaki Miyanaga, Yotaro Nishikawa, Haruhiko Koseki, Narantsog Choijookhuu, Yoshitaka Hishikawa, Yoshihiro Yamashita \& Katsuaki Sato
\end{abstract}

Correction to: Scientific Reports https://doi.org/10.1038/s41598-020-65355-9, published online 20 May 2020

This Article contains errors in the Methods section, under the subheading 'Generation of $\mathrm{Cd}_{103^{-/-}}$mice',

"The linearized targeting construct was introduced by electroporation into C57BL/6-derived JN/2 recombinant embryonic stem cell (ESC) and neomycin-resistant clones were first screened for homologous recombination by PCR utilizing a pair of the following oligonucleotides: Primer 1 (5'-ATA TGT AGT GTC TGG TCA GGA TAA TAG TTG- $3^{\prime}$ ) and Primer 2 (5'-ATA ACC TCC TCT CCT ATG GTA CCT AAA C-3')."

should read:

"The linearized targeting construct was introduced by electroporation into C57BL/6-derived JN/2 recombinant embryonic stem cell (ESC) and neomycin-resistant clones were first screened for homologous recombination by PCR utilizing a pair of the following oligonucleotides: Primer 1 (5'-ATA TGT AGT GTC TGG TCA GGA TAA TAG TTG-3') and Primer 3 (5'-ATA ACC TCC TCT CCT ATG GTA CCT AAA C-3')."

"Transmission of the targeted allele was confirmed by PCR with Primer 1 and Primer 3 (5'-CTT TAT ATT TCA TTT TTG CTC AGG CTT C-3'). The mutant mice were cross-mated for more than nine generations with B6.FLIP mice to excise the flanked FRT sites by Flp-recombinase, and 8 - to 12 -week-old $C d 103^{+/+}$littermates were used as WT mice. Then, $C d 103^{+/-}$littermates were crossed to obtain homozygotes, and transmission of the targeted allele was confirmed by PCR with Primer 1 and Primer 3."

should read:

"Transmission of the targeted allele was confirmed by PCR with Primer 1 and Primer 2 (5'-CTT TAT ATT TCA TTT TTG CTC AGG CTT C-3'). The mutant mice were cross-mated for more than nine generations with B6.FLIP mice to excise the flanked FRT sites by Flp-recombinase, and 8- to 12 -week-old $\mathrm{Cd}_{103^{+/+}}$littermates were used as WT mice. Then, $C d 103^{+/-}$littermates were crossed to obtain homozygotes, and transmission of the targeted allele was confirmed by PCR with Primer 1 and Primer 2."

(1) Open Access This article is licensed under a Creative Commons Attribution 4.0 International License, which permits use, sharing, adaptation, distribution and reproduction in any medium or format, as long as you give appropriate credit to the original author(s) and the source, provide a link to the Creative Commons license, and indicate if changes were made. The images or other third party material in this article are included in the article's Creative Commons license, unless indicated otherwise in a credit line to the material. If material is not included in the article's Creative Commons license and your intended use is not permitted by statutory regulation or exceeds the permitted use, you will need to obtain permission directly from the copyright holder. To view a copy of this license, visit http://creativecommons.org/licenses/by/4.0/.

(C) The Author(s) 2020 